\title{
Hoshin Kanri and its Diffusion among Argentine SMEs
}

\section{Hoshin Kanri y su Difusión en PYMEs Argentinas}

DOI: $10.46932 /$ sfjdv2n2-171

Received in: March 1st, 2021

Accepted in: May 30th, 2021

\section{Dr. Eng. Antonio Adrián Arciénaga Morales}

Institute of Industrial Engineering and Development of Salta (IIDISA) - Engineering Faculty, National

University of Salta, Salta, Argentina.

Address: Av. Bolivia 5150, C.P. 4400 Salta

E-mail: aarcienaga@gmail.com

\section{Spec. Eng. Bárbara Magdalena Villanueva}

Institute of Industrial Engineering and Development of Salta (IIDISA) - Engineering Faculty, National University of Salta, Salta, Argentina.

E-mail: lacuentadebarbara@hotmail.com

\section{Msc. Eng. Héctor José Solá Alsina}

Institute of Industrial Engineering and Development of Salta (IIDISA) - Engineering Faculty, National

University of Salta, Salta, Argentina.

In memorial. This article is dedicated to his memory.

\begin{abstract}
The Hoshin Kanri is a strategic planning system that possesses the particular capability to solve the most typical problems of implementing such a plan, within organizations. Its Japanese origin has not been an obstacle for its adoption and implementation in firms and organizations of different origins, as this article shows. There still are many difficulties and few experiences for implementing it in SMEs, both in Argentina and at the international scale. The work's objective is to describe Hoshin's planning, providing evidence of its Argentine dissemination, and analyzing the feasibility of its implementation within domestic SMEs. Finally, some necessary conditions for implementing Hoshin are detailed, most of them of operative character, considering some of the specific features of this type of firm.
\end{abstract}

Key Words: Hoshin Kanri, strategic management, SME, implementation.

\section{RESUMEN}

El Hoshin Kanri es una herramienta sistémica de planificación estratégica que posee la importante capacidad de resolver en gran medida problemas típicos de la implementación de un plan de esta naturaleza en las organizaciones. Su origen japonés no ha sido un obstáculo para su adopción e implementación en entidades de otros países, como se ha podido documentar. Hay todavía dificultades y pocas experiencias en la implementación en PYMEs, tanto en Argentina como a escala internacional. Este trabajo ha tenido por objetivo describir este sistema de gestión estratégica, documentar su difusión en Argentina, y analizar las posibilidades de implementación en las PYMEs nacionales. Se detallan al respecto algunas condiciones necesarias de implementación, de carácter operativas, asociadas a las características que le son propias a este tipo de empresas.

Palabras Clave: Hoshin Kanri, gestión estratégica, PYMEs, implementación. 


\section{INTRODUCTION:}

Traditional economic models, based on the assumption of perfect competition, attribute to companies rules of behavior that are as precise as they are unavoidable. In this approach, the company does not have any space left for the development of a voluntary and creative action to defend or improve its position in the market. However, in the last six decades there has been a notable change: the company ceases to be conceived as a passive entity that follows fixed market rules, to become an active agent that outlines strategic responses to the changing structures and conditions of the environment, and your own resource constraints. Business results depend, to a large extent, on those answers. Thus, the concept of business strategy -or strategic management- was born in the sixties. It presupposes a change in the way of conceiving the relationship between the company and its environment. The changing reality of the markets is appreciated, and the possibilities that companies have are assumed to influence similar transformations with the resources and capacities available internally. The environment ceases to be an immutable parameter, to become an area subject, at least to some extent, to the influence and the companies' capacity for action and maneuvering.

One of those tools is the Hoshin Kanri, a true strategic management system ${ }^{1}$ that appeared in Japan in the early 1960s, in parallel with the statistical process control, and closely linked to Total Quality Management (Cudney, 2009: 16; Witcher, 2014: 77). Its basic task is the elaboration and implementation of an annual policy that crosses the entire organization, passing through all its departments and functions. It is a management system that is not only participatory, aligning the objectives of the organization with those of its members (Kondo, 1998: 295), but also progresses towards an organization that learns.

The main objective of this work is to describe Hoshin Kanri, given its degree of novelty for most Argentine companies and universities, and then to analyze its possible application in small and mediumsized enterprises (SMEs). For this purpose, section 2 analyzes conceptual aspects of this strategic management system, trying to capture its deepest rationale. There are in this epigraph the types of problems that Hoshin Kanri can attack, to explore the scope of this Just in Time (JIT) or Lean Production tool. Then, section 4 describes the way and the tools with which Hoshin Kanri is deployed in an organization, in order to understand its operation and dynamics within a company. As a concluding remark, strategic planning and its possible implementation in stages with this instrument are analyzed. In section 6 there is a brief discussion of its application in the Argentine reality, with a review of the application experience of this management system in SMEs, ending this work with some general conclusions and recommendations.

\footnotetext{
${ }^{1}$ Hoshin Kanri is a true system integrated by several tools and arrangements, which work together with a systemic rationale for implementing agreed-upon strategies, assessing their performance, and reviewing them (Bryson, 2011: 323). The components will be described later.
} 


\section{THE CONCEPT:}

The Japanese term Hoshin Kanri does not have a direct translation into Spanish. The first "word", Hoshin, is made up of the terms Ho which in Japanese means needle, and Shin which resembles shiny metal. Therefore, it is usually translated as compass or direction. In addition, the term Kanri is decomposed into Kan which is equivalent to alignment, and $R i$ which means reason, with which it can be translated as administration or control. Therefore, Hoshin Kanri can be translated as "the compass of senior management" (Hutchins, 2008: 3) ${ }^{2}$. The 'Hoshin Kanri' term appeared first in an internal document of the Japanese company Bridgestone Corporation, in 1962, which combined Hoshin Kanri with total quality control, following the methodologies used in the Deming Prize, the national award for quality in Japan (Witcher, 2014: 77; Kondo, 1998: 425).

Therefore, this tool finds its best meaning and scopes when it is interpreted from the rationale of JIT or lean production ${ }^{3}$. Furthermore, many firms fail in implementing operational tools of lean production because they expect short-term results and do not connect the JIT tools with global strategies, going back to old techniques (Ayala, 2010: 13). Hoshin Kanri can solve clearly these problems of a lean production implementation.

Conceptually, Hoshin Kanri encompasses four key elements or aspects in business management: Mission and Vision, Policy Development, Policy Deployment, and Control Policies. It is also connected to a fifth tool such as the Total Quality Management System (TQM), through which the achievement of the goals determined by Hoshin Kanri and their control is executed (cf. Hutchins, 2008: 2).

\footnotetext{
${ }^{2}$ A non-literal translation of Hoshin Kanri agreed upon, would be the following (Jolayemi, 2008: 296; Boisvert, 2012: 3): Hoshin = a compass of direction, a course of action, a policy, a plan, an objective. Kanri = management, control of the focus of a company.

${ }^{3}$ The western version of the Hoshin Kanri was essentially due to Hewlett Packard (HP), which created a joint venture in Japan called Yokagawa HP, which adopted total quality management in 1977 and won the Deming Award for quality in Japan in 1982. HP had previously implemented a management system based on management by objectives, which was combined with Hoshin Kanri through this joint venture. This resulting tool became mandatory for the entire corporation in 1985 (cf. Witcher and Butterworth, 2000: 72).
} 
Figure 1. Components \& Relationships in Hoshin Kanri. Source: with own modification on Hutchins (2008:3).

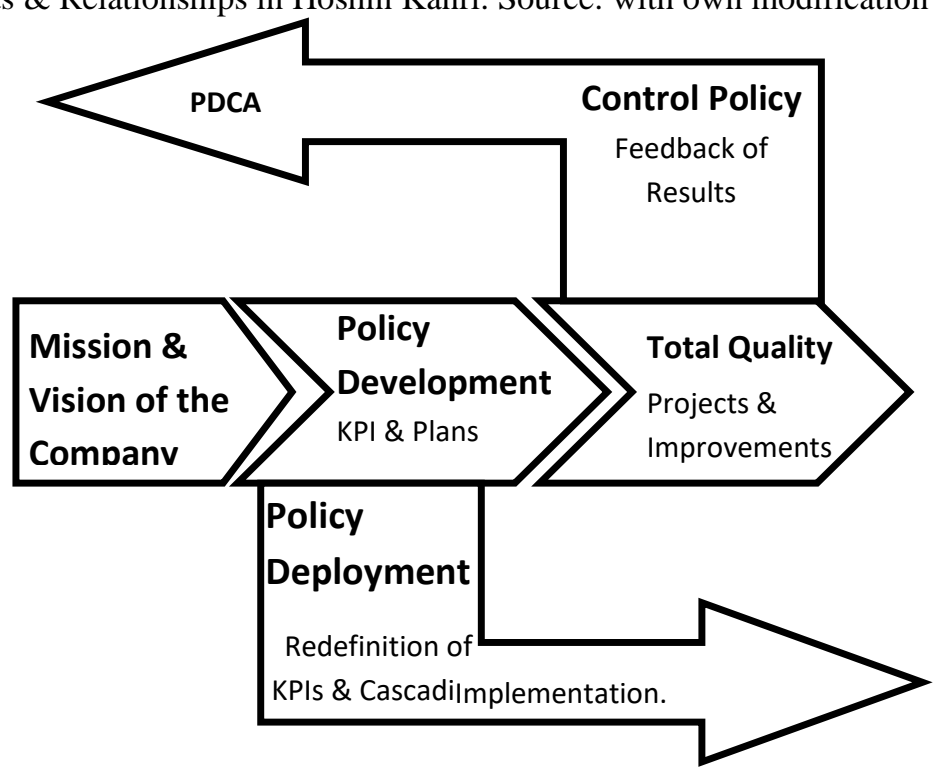

Note: KPI is the acronym for Key Performance Indicators.

Figure 1 shows the relationships adopted by these four components and their connection with the TQM, particularly with the improving circle $\left(\mathrm{PDCA}^{4}\right)$. This connection has to do with the origin of this management system, closely linked to TQM, to the point that Hoshin Kanri was initially described as the application of the PDCA cycle for the planning and execution of a few critical organizational strategic objectives (cfr. Witcher, 2014: 78). As a management system, some of the core features that differentiate Hoshin Kanri from other strategic planning systems are as follows ${ }^{5}$ :

- It generates knowledge and organizational intelligence, throughout the company (not only in senior management), around its policies.

- It proposes a true cascade deployment of the strategic function, through all its departments, making the strategy a task for all.

- Overall organization's goals are integrated with daily work, even in the operational line of production (Tennants and Robert, 2001: 287).

- Objectives and goals can be important qualitative leaps for the organization, even radical innovations and/or breakthrough leaps ${ }^{6}$.

- It provides a precise focus of attention to the management of the company by establishing a reduced set of strategic priorities, on an annual basis.

- The tool aligns these strategic priorities with the company's plans and programs.

- Strategic priorities are integrated with day-to-day management.

\footnotetext{
${ }^{4}$ PDCA: Plan, Do, Check, and Act. Four basics steps for continuous improvement.

${ }^{5}$ See among other references Cudney (2009: 16-20), Hutchins (2008: 2-5), Tennants and Roberts (2001: 287-9).

${ }^{6}$ This makes it compatible with prospective tools based on future scenarios, or futuribles (in French).
} 
- It provides a structured review of progress in achieving strategic priorities.

- It generates convergent purposes for each organizational function and activity, focusing the staff behind agreed strategic objectives, set by management.

- Self-control processes are introduced, coherent with the JIT philosophy.

- Intra-business communication are works with some interesting JIT techniques.

- The tool improves internal coordination of an organization, essentially revaluing the mechanisms of mutual adjustments ${ }^{7}$, based on continuous improvement in the internal communication.

- Hoshin Kanri is integrated with other Lean Production or JIT tools, constituting almost an obligatory step in the evolution of kaizen, TPM, TQM, among others.

- It guarantees the availability in time and form of necessary resources to ensure that the strategic objectives will be achieved at all levels of the organization.

\section{STRATEGIC PROBLEMS THAT HOSHIN KANRI CAN ADDRESS:}

Every organization has central problems that make strategic planning difficult and complex, but above all, they affect the processes of planning implementation. Among the main problems, general or specifically related to Hoshin Kanri, the following can be pointed out (Hutchins, 2008: 6-7; Tennants and Roberts, 2001: 2090-91; Boisvert, 2012: 2-3):

- Poor vision of the future and the projection of the company, in most of the personnel.

- Non-financial management indicators are normally qualitative and not quantitative, which makes decision-making and management (strategic and also day-to-day) difficult.

- Scarce certainty or awareness of the direct competitors' strategy or performance.

- Decision-making is to a large extent based on opinions and not on facts or factual data, which generally increases conflicts due to essentially subjective issues and hinders internal agreements and consensus.

- When decisions are based on data, these are generally from accounting sources and therefore out of date. The current cradle of data and indicators appears as a critical bottleneck for making informed decisions. Either way, when data is stored in separated silos within an organization, following traditional procedures or reinforcing internal power construction, there are barriers to deploy some communication tools of Hoshin Kanri. These barriers also make more difficult the implementation process as a whole.

- The culture of the company sometimes blames to certain actors (scapegoats) when things go wrong. In other words, the error is personalized instead of objectifying for solving it.

\footnotetext{
${ }^{7}$ Coordination by mutual adjustments was replaced by Fordism-Taylorism by supervision. However, mutual adjustment has been revalued in innovative organizations and in knowledge management.
} 
- Middle managers suffer from insecurity, lack of appropriate power, insufficient training, or are lately involved in strategic processes, so they are reluctant to implement the plan.

- Departmental goals are not necessarily the entire organization's goals.

- Many of the solutions applied to internal problems are quick, designed by and for the situation, but not sustainable, and lack a systemic vision of the organization.

From the overall perspective of strategy, there are some other known problems, specific for implementation, i.e. the process of putting strategies into action. Among the most critical issues, there can be pointed out the following: unsuitable training of managers focused on planning but not on executing; loss of the initial momentum before the expected benefits are realized; lack of competencies for managing change effectively and overcoming resistance to change; a poor or vague strategy that avoids everyone truly understands and agrees to execute; lack of guidelines or a model to guide strategy implementation efforts; silo-organization or inadequate information sharing among individuals/units responsible for strategy execution; implementing a strategy that conflicts with the existing power structure; unclear responsibility or accountability for implementation decisions or actions (Hrebiniak, 2006: 17-18; Raps, 2005: 141; Lorange, 1998: 27-28). Hoshin Kanri can also solve these common problems of strategy implementation.

In Figure 2 an attempt is made to graphically illustrate these problems. Although it is difficult to capture largely intangible issues in a diagram, this figure attempts to highlight issues related to poor communication, the lack of alignment of objectives at the different levels, the forms of decision-making at each of the levels, the loss of organizational energies, emerging conflicts in the framework of the operation of an organization, and troubles in implementing strategies.

Faced with these problems, the system proposed by Hoshin Kanri provides interesting solutions in this regard: a) management is not done by functions, as in traditional hierarchical pyramid companies, but by processes that are intended to provide high returns; b) The strategic plan is deployed (implemented) as a process in which it is made known to the entire organization, which substantially improves the participation and contributions of each of the areas and departments in achieving the strategic objectives. 
Figure 2. Organizational Strategic Problems. Source: modified from Hutchins (2008:7).

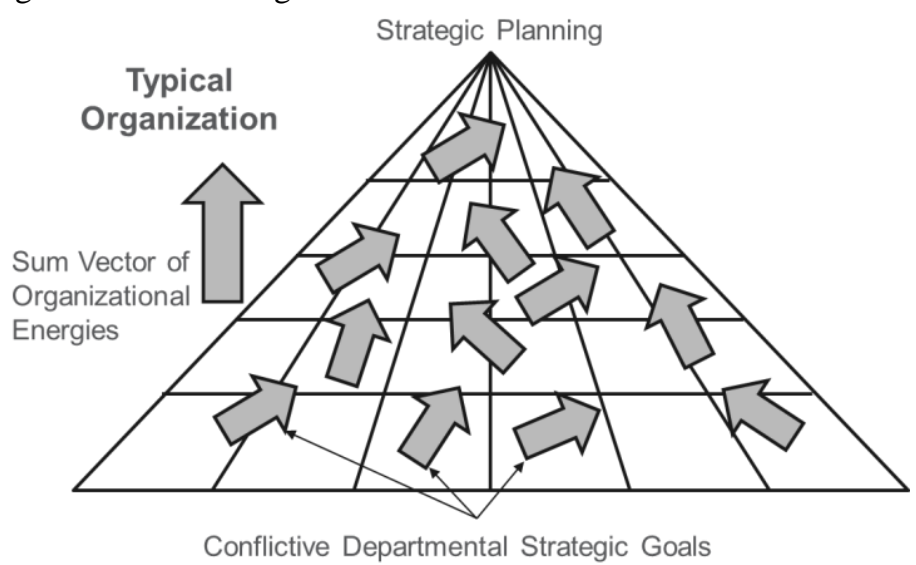

As a third solution, the Hoshin Kanri aligns all the levels and goals of the organization, while also making the latter relevant to the changes in the environment (Figure 3). Each goal implies a challenge with managers, deadlines, and resources, which are mobilized together with the entire organization, at each of its hierarchical levels, through the Improving circle or PDCA. For this purpose, the Hoshin Kanri is proposed as an organizational framework that focuses its attention on the entire organization. It tries to align the priorities of senior management with plans and actions at all organizational levels, integrating the strategy even in day-to-day management.

This framework ensures organizational learning at different levels and the adaptation of plans and actions through a permanent review of them (cf. Witcher and Butterworth, 2000: 71). Therefore, a basic principle of Hoshin Kanri is that everyone in an organization should make a contribution to the core issues and goals of the company, within the assigned work.

Figure 3. Effects of Hoshin Kanri on the Organization. Source: Hutchins (2008:8).

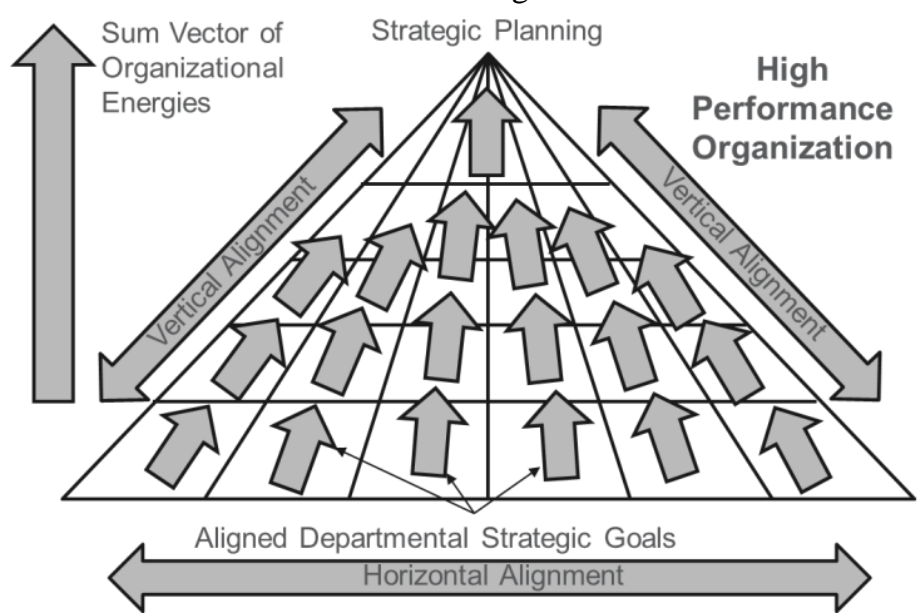

This effort and awareness of all for the central organizational issues and goals contribute significantly to the improvement of the company (Figure 3). Therefore, it can be pointed out that the 
Hoshin plan requires an alignment process, in a cascading discussion within the organization, as a key way to deploy the plan.

\section{HOSHIN KANRI'S DEPLOYMENT:}

In order to understand the dynamics of Hoshin Kanri's deployment, it is necessary to know what the general Hoshin process or strategic plan is. Figure 4 shows the particular stages that this tool has, different from other traditional forms of strategic planning.

Figure 4. General Process for Hoshin Kanri. Source: with modifications from Boisvert (2012:3).

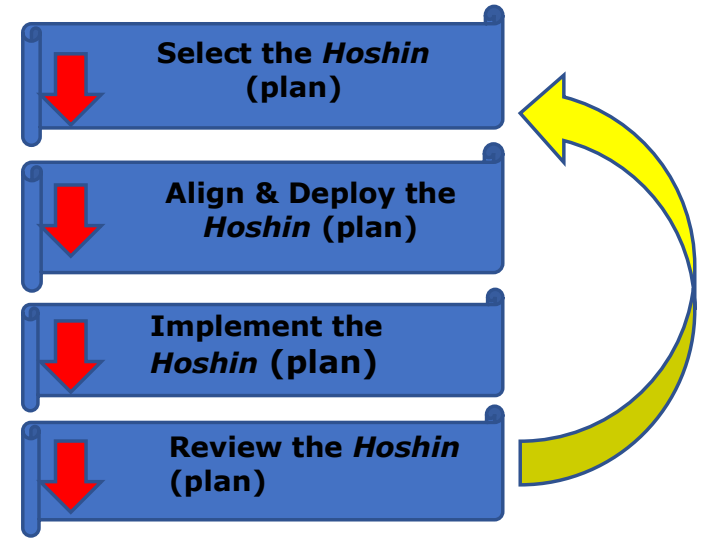

The selection or identification of the plan has the ingredients of any plan: mission analysis, vision, SWOT matrix, five competitive forces. They are already classic planning tools. Unlike these tools that privilege the analysis of the environment and then place the company and its actions in it, Hoshin proceeds in the opposite direction. From its own resources and capacities, it analyzes the possibilities of change in the organization, even a rupture change, and designs the necessary actions in consensus to achieve the objectives set by the management. The approach resembles the theory of the resource-based company (Witcher, 2014).

The main differentiation of the Hoshin Kanri is in the alignment ${ }^{8}$ and the deployment of the plan (Figure 4). For the latter, the processes have to do with the use of two communication tools: catchball and nemawashi. The first consists of an open process of dialogue between two parties, leading to putting underlying negotiation processes on track in an orderly and less conflictual manner. Internal communication, both vertical and horizontal, is a participatory process associated with the decisionmaking process, for which information and ideas are launched between the different levels of the

\footnotetext{
${ }^{8}$ The problem of the alignment of individual behaviors with the general goals of the organization is a central issue to be solved in strategic management (cf. Drucker, 1992: 96). Hoshin Kanri proposed an organizational dynamic that has some common edges with management by objectives, but that clearly has different instruments. In balance scorecard, the alignment performed in a very similar manner to Hoshin Kanri as a central feature (Olve et al, 2003: 3). It should be noted that balance scorecard appeared as a methodology in the early 1990s in the USA, almost 30 years after Hoshin Kanri.
} 
company, in one direction and the other (top-down and bottom-up, and horizontal between groups), to make effective internal communication. The metaphorical launch of ideas allows to clarify priorities, resolve doubts and questions, identify how to execute actions, link objectives and strategies with the daily work at each level, build consensus and ensure that strategies, objectives, goals, and actions are well understood by the organizational actors involved.

Besides, aligning problems to a great extent are communication and coordination issues for the components of an organization ${ }^{9}$. Bringing a team or an organization rowing in the same direction, i.e. strategic alignment or fitting, is quite significant for both the formulation and the implementation of the organizational strategy. Hoshin Kanri gives equal importance to vertical and horizontal (or lateral) fittings (Figure 3). "Alignment requires a shared understanding of organizational goals and objectives by managers at various levels and within various units of the organizational hierarchy" (Kathuria, Joshi, and Porth, 2007: 504). Well executed as in Hoshin Kanri, strategic alignment significantly and positively affects decision effectiveness (Ghonim et al., 2020). From a SMEs' point of view, Barth (2003) highlighted that the lack or absence of alignment is an indicator of the lack of strategy.

The Hoshin Kanri begins (Figure 5) with the identification of goals, objectives and strategic plans to be achieved. These elements are communicated to the next level in the hierarchical line, using the "catchball" to understand the information provided, evacuate doubts, and interpret how one will contribute at their level to the achievement of goals set by the higher level. The flow of information directly or indirectly generates a negotiation in the making, since by turning the "ball" upwards, the receiver can also understand the viability or not of the goals and objectives set, about the commitments that it generates downwards in the organization, on the real possibilities of its execution, among others. The "catchball" is repeated at each hierarchical level. The process must be developed to ensure feedback on a multidirectional horizon (Tennants and Roberts, 2001: 292). Therefore, putting in parallel and close connection the formulation and implementation of an organizational strategy, Figure 5 shows how to perform the alignment process within Hoshin Kanri.

\footnotetext{
${ }^{9}$ Tosti and Jackson (2001) defined alignment as a process of linking organization's critical internal factors such as strategy, culture, processes, people, leadership, and systems for the purpose of accomplishing common goals.
} 
Figure 5. Hoshin Kanri Deployment. Source: own elaboration on the base of Cudney (2009:35-37).

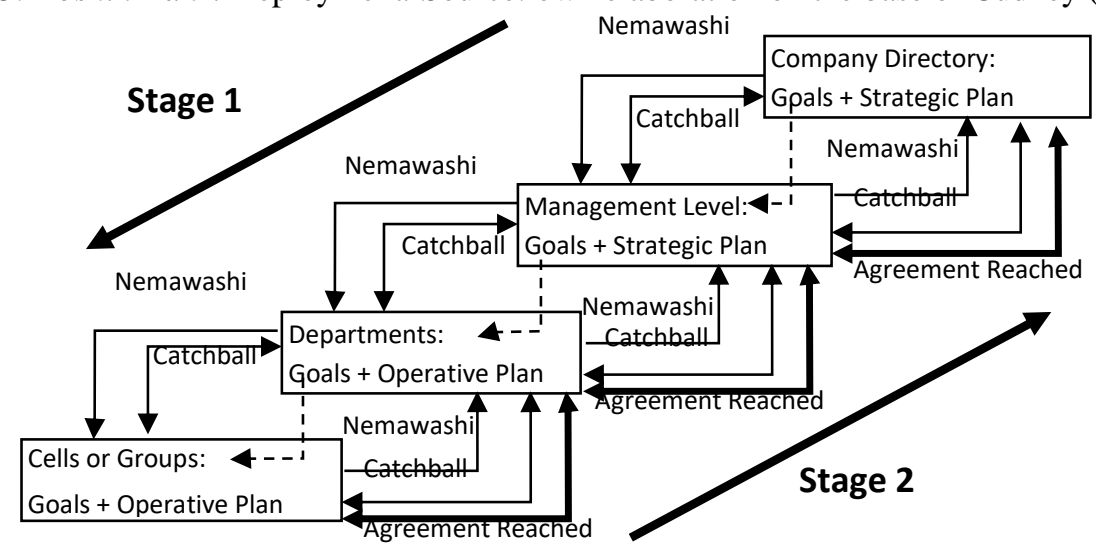

With regard to "nemawashi", the second communication tools of Hoshin Kanri, it is generally applied together or before the "catchball". Nemawashi allows participants to understand the full meaning of preliminary goals and plans. Parallel to the explanations, detailed information (catchball) is formally communicated to understand the scope and meaning of the ideas at stake. Nemawashi is an informal organizational process to patiently generate consensual bases for a proposed change or a new project or deliberate action. The key is in an open dialogue of those involved to understand meanings, thus achieving feedback of information and the personal support of the interlocutors. The key figure is the coordinator, responsible for promoting group consensus. This tool, unlike the West, bases the decision-making process on harmony, negotiation, and consensus.

Nemawashi means "to go round the root." The metaphor is that to transplant a plant, the root and enough earth around it are essential for surviving when planted elsewhere (Masai et al., 2017: 59). The same process occurs with the transplantation of an idea. It is necessary to understand the roots or meanings to capture well the nuances that said idea carries. The nemawashi serves to prepare the ground for new ideas, such as a strategic plan and its objectives, in advance of its implementation (O'Gorman, 2012), and the catchball contributes with enough earth. The communication features of nemawashi is also a critical factor for implementation (Miniaces and Falter, 1996). Therefore, ideas are expected to be captured, understood, communicated, and implanted, for surviving and thriving ${ }^{10}$.

As can be shown in Figure 5, the Hoshin Kanri unfolds as follows:

- In Stage 1, prior to the formal submission of the plan and its goals, the board of directors has an open dialogue using nemawashi to obtain a prior consensus.

- The plan and its goals are officially sent from the board to the next lower level.

- Catchball is used to adjust data, scope, priorities, resolve doubts and questions.

\footnotetext{
${ }^{10}$ Nemawashi process can be also characterized as an ontology by three types of entities: its participants, the items that belong to the Hoshin Kanri level, and the specific project considered for adoption. See Masai et al (2017: 60).
} 
- The received plan is translated into priority goals for the hierarchical level in question.

- Nemawashi is applied between this hierarchical level and its immediately lower one.

- The plan and its objectives are formally sent to the immediate lower level.

- This double combination between catchball and nemawashi is carried out in a cascade until reaching the operational line, generally represented by cells and/or groups of workers.

- Cascading enhances the Hoshin Kanri with the experience of all the participants. This means that every person in the organization is allowed to contribute with ideas. However, participants have seniority and expertise, which increase the probability to include their proposals in the nemawashi process (Masai et al., 2017: 64).

- Cascading also encourages strategic delegation of responsibility, contributing to developing capabilities and self-development of persons and groups.

- Within Stage 2, the developed plan circulates in a bottom-up process. It is agreed upon and then communicated between levels.

- Plans circulate in ascending order while they are adjusted with nemawashi and catchball in each level, as in Stage 1. Individual and group contributions are particularly gathered here.

- The agreed plans are executed using the PDCA cycle or improving Circle.

- In both Stages, the involved processes require the combination of strategic competencies, planning capabilities, operational expertise, and administrative skills for designing and implementing the Hoshin.

- The prioritized problems and/or opportunities to solve are broken down and linked vertically and horizontally, facilitating their solutions.

\section{PLANNING AND IMPLEMENTING HOSHIN KANRI:}

Strategic planning using Hoshin Kanri is carried out according to the following stages ${ }^{11}$ :

a) Clearly establish the vision of the company for the long term (a horizon of 3 or 5 years in normal times). It is advisable to synthesize a slogan or mantra that reflects the vision, strategies, the quality policy, and the action plan.

b) Make a list of strategic objectives: these are specific, realistic, achievable, measurable and longterm (SMART mnemotechnics), necessary for long-term success. The less they are, the better. Set them annually.

\footnotetext{
11 This list of stages is based on the preliminary work of Akao (1991), particularly in its Chapter 5 that deals with 10 stages in implementation, which are based on case studies (Hewlett Packard, Florida Power \& Light, and Xerox). We have modified and merged two of them. Wood and Munshi (1991) present a similar model for implementing Hoshin Kanri. In both approaches, Hoshin Kanri is presented as part of TQM.
} 
c) Make a list of Strategic Goals of the company: major goals (next 3 to 5 years), consistent with the mission / vision of the organization.

d) Identify the strategies / actions for each Objective. This means planning well the objectives, goals, and strategies (what to do) and the means (how to do).

e) Analyze the coherence between objectives, goals, and strategic actions.

f) Identify indicators to measure the results achieved (KPIs), and their respective base values and target values, and list of results control indicators.

g) Identify those responsible for specific goals and actions. This is precisely the central process for the deployment of policies, monitoring of actions, and control of indicators.

h) Identify how improvements in each goal and objective will be measured, through proposed actions, using the KPIs already defined. That is, implement the plan understanding how to manage objectives through the catchball with the participating agents.

i) Agreements on the form of monitoring the actions in execution, as well as the partial and final milestones to be observed, incorporating the suitable adjustments where necessary. Follow-up includes a periodic report for management ${ }^{12}$.

Figure 6: Design of Hoshin Plan. Source: own elaboration on the base of Boisvert (2012:4).

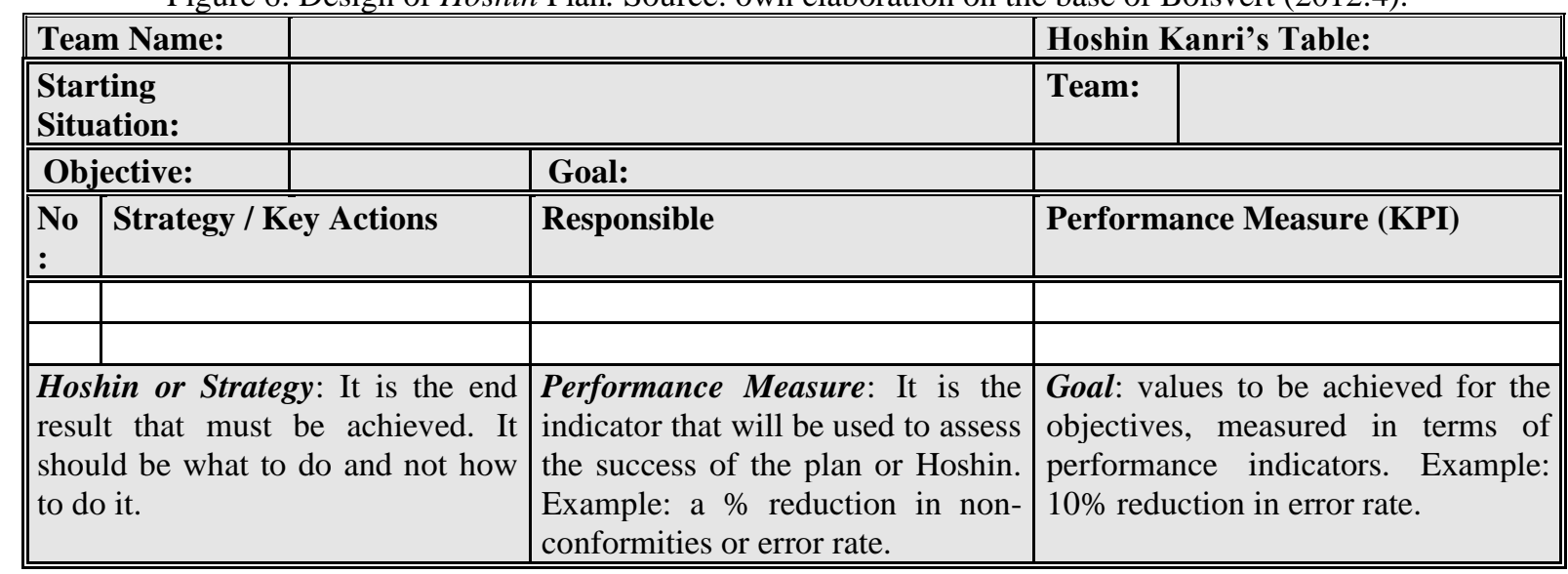

Figure 6 above shows how to systematize these variables necessary for the design of the Hoshin Kanri. It contains the basic information that can be circulated in Stage 1, and the possible agreements to be reached and achieved in Stage 2, following the sequence in Figure 5.

Within the implementation phase, it is necessary for the success of the process to carry out actions at each hierarchical level of the company. In such a way, Hoshin Kanri works on producing a cascade alignment effect. The actions, divided into phases, are as follows:

\footnotetext{
${ }^{12}$ Software can be used here to support daily improvement, reports, and follow-up of goal management.
} 
- Phase 1: Implementing the system of performance indicators that will be used to evaluate the progress of the plan, at each level. This system should be reviewed regularly.

- Phase 2: Surveying the business environment to understand the needs and satisfaction of customers, in relation to competitors. Verify the chosen indicators.

- Phase 3: Providing the necessary resources for the development of the actions. The commitment of resources is central to the success of the plan (effective management commitment).

- Phase 4: Periodically review of the results achieved for each of the agreed strategic objectives. Catchball can be used to improve this task.

- Phase 5: Verification if with Hoshin Kanri the organization improves its ability to predict or anticipate the future and to respond to changes in the environment.

- Phase 6: Annually review of the Plan as a whole.

More recently, Dennis (2006) and Jackson (2006) presented different models for implementing Hoshin Kanri. They emphasized Hoshin implementation as part of lean production strategies, taking into consideration the Toyota Experience. Jackson (2006) suggested a new SPDCA circle (scan-plan-docheck-act), where scan involves defining and reviewing the mission, vision and long-term strategies for the organization. Both authors use the A3 thinking, which is a crucial tool of management in Toyota. A3 is a tool for reporting ${ }^{13}$, but it reflects seven key elements behind its rationale (Sobek II and Smalley, 2008: 12-18): i) logical thinking process; ii) objectivity; iii) results and process; iv) synthesis, distillation, and visualization; v) alignment; vi) coherence within and consistency across; vii) systems viewpoint.

Toyota's strategy deployment is highly based on the use of A3 as a tool for communication and reporting. All the critical factors, data, and information are recorded on an A3 sheet of paper. Jackson (2006) introduces the idea of four teams for deploying the strategy: the Hoshin team (with top management personnel working in long-term), tactical team (qualified experts for setting strategic goals in the nearterm), operational team (people that carry out and supervise standard processes to support tactical plans), and action team (with cross-functional groups working on daily tasks). He also suggested a new form of A3 for Hoshin plans, called X-Matrix (center of Figure 7). This tool sums up in a single document the strategies, tactics, processes, results, individuals, and groups involved in the Hoshin plan. It also combines long, near, and short-term initiatives, communicating these data effectively on one page. Figure 7 shows all these factors and their relationships.

\footnotetext{
${ }^{13}$ A 3 is just a paper size but gives the name to this tool. The idea is to bring all the information on one sheet of paper. This format tells the story, starting from the upper left side to the lower right, in an easy way to be understood. A3 makes it easier to engage others and fosters dialogue within the organization. A3 connects very well with Hoshin Kanri, particularly within the alignment process (Figure 5).
} 
Figure 7: X Matrix for a Hoshin Plan. Source: with modifications from Jackson (2006: 7).

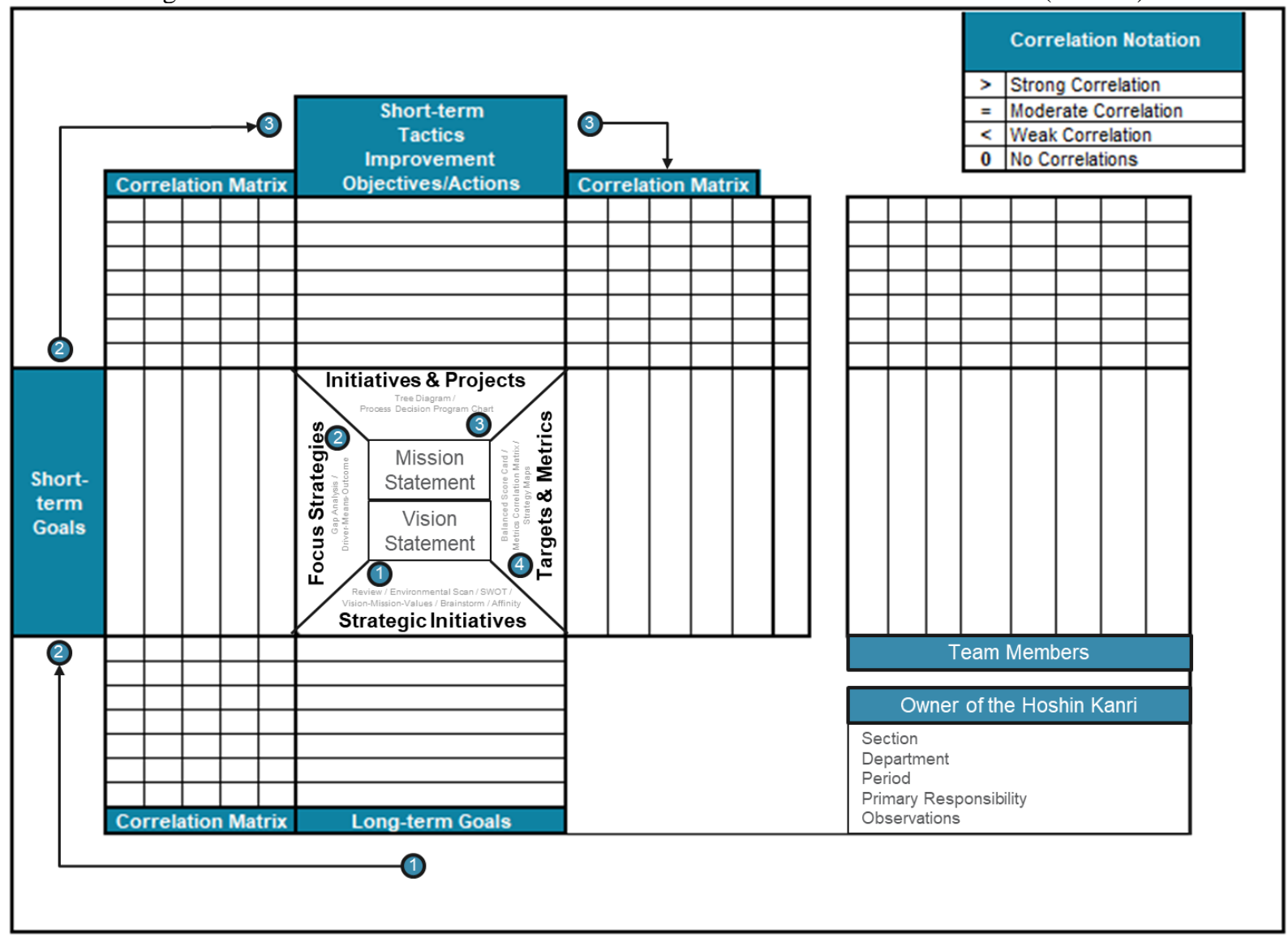

The beginning on this X-Matrix is strategic initiatives, which are highly prioritized strategies, for the long term (following 2 to 3 years). These initiatives give rise to tactics that are improvements projects for the current period (12 months). In turn, tactics require measures of process improvements as specific projects. Fourth, process improvements yield results, like financial, operatives, and social impacts. Connecting all these four blocks there are correlation matrices that record interrelationships between these critical factors for strategies. Finally, people required (individuals, groups, teams, and even suppliers) are also recorded, including their patterns of cooperation (for alignment). This X-Matrix is particularly useful for SMEs due to its simple design, as it will be argued in the next section.

\section{CONSIDERING HOSHIN KANRI IMPLEMENTATION IN ARGENTINA:}

The dissemination and application of strategic management through Hoshin Kanri has been carried out in Argentina by three different agents. The objective of this section is to describe the diffusion patterns followed in Argentina and to analyze the possibilities of applying this management tool to SMEs. In the first place, it can be pointed out the introductory role played by the subsidiaries of multinational companies, which had the implementation of strategic plans through Hoshin Kanri management systems at their headquarters. The first company to mention is the Bridgestone Corporation, a pioneer in the 
original development of the system (Kondo, 1998: 425), which was established in Argentina through the purchase of the US Firestone in the late 1980s, including its subsidiary branch in Argentina. In the mid1990s, after almost five years of the merger process, Bridgestone Argentina began its strategic planning process with Hoshing Kanri tools, following the directives of its parent company.

Other multinational subsidiaries that also used planning derived from Hoshin were HP, the first Western corporation that adopted Hoshing Planning for all its businesses and subsidiaries in 1985, making it compatible with its management by objectives and total quality management system (cfr. Witcher and Butterworth, 2000: 72). Bridgestone Argentina and HP Argentina were the first experiences of Hoshin Kanri disseminated in the country ${ }^{14}$. It is worth mentioning that, in Brazil, the early book of Campos (1996), in Portuguese, played a decisive role in the diffusion of Hoshin Kanri among the big local firms or even subsidiaries (Ayala, 2010: 42). On the contrary, in Argentina, there was not much literature in Spanish on this subject.

The second group of actors disseminating Hoshin Kanri in Argentina were some non-profit institutions. The first to be mentioned is the AOTS, Argentina Kenshu Center, a private Japanese organization for international cooperation with a subsidiary in Argentina, in particular the AOTS Center for Training and Consulting in Japanese Management. This entity has been crucial in Argentina in the dissemination of Hoshin Kanri through agreements with the National Institute of Industrial Technology, National Technological University (UTN), by their own consulting and training services, and by the Fundación Exportar (Export Foundation), in the last fifteen years.

In the AOTS webpage, they mention 400 firms and organizations that have received training or consulting services on lean production tools in their Center in the last period. Further characterizations of these 400 organizations can be the following: $12.00 \%$ are branches of multinationals firms; $5.50 \%$ are big firms (multinational and national firms), and $82.50 \%$ are SMEs. It is worth mentioning that $2.00 \%$ (i.e. 8 organizations) and $3.75 \%$ (i.e. 15 governmental entities) are sectoral chambers and governments of different levels respectively, which can amplify the effects of diffusion. A high percentage of firms belong to metalworking industries, particularly those in subcontracting chains with multinationals that have implemented lean production ${ }^{15}$. AOTS supports these organizations with different lean tools. However,

\footnotetext{
${ }^{14}$ Other multinational companies with subsidiaries in Argentina, which also adopted Hoshin Kanri in the late 1980s, were Texas Instruments, Xerox, Procter \& Gamble, AT\&T, IBM and Compaq (Witcher and Butterworth, 2000: 71; Jolayemi, 2008: 295 ). There is also Toyota Argentina, whose parent company also played an important role in the development of the Hoshin Kanri in Japan in the '70s (Marksberry, 2011: 348). More recently, at the beginning of this century, Nissan Argentina has adopted Hoshin Kanri as other branches of the firm (Witcher et al., 2008).

${ }^{15}$ The different economic sectors that receive this support are: Agriculture 5.25\%; Mining 1.25\%; Chemical Industry 4.50\%; Construction Materials 0.50\%; Plastics Industry 1.75\%; Food Industry 8.00\%; Graphic \& Paper Industry 1.75\%; Electric al \& Electronic Appliances 5.25\%; Metalworking Industry 20.25\%; Glass Industry 0.75\%; Construction Industry 3.25\%; Software $3.00 \%$; Toy Industry $0.25 \%$; Wood \& Furniture Industry $1.75 \%$; Oil, Gas, \& Renewables 3.00\%; Leather, Textile, \& Footwear Industry 5.75\%; Electricity Production 1.25\%; Consulting Services 7.75\%; Other Services 8.25\%; Financial Services 4.25\%;
} 
for implementing lean production operational tools, organizations require a long-term vision and results. This vision is closely connected with the JIT tools for global strategies, as Hoshin Kanri. In turn, Hoshin can also facilitate solving common problems of lean tool implementation. Therefore, AOTS is a great contributor to the dissemination of Hoshin Kanri in Argentina.

Another important institution is SAMECO, a nonprofit NGO for Kaizen diffusion, which develops activities and training related to lean tools and the Hoshin plan in the last 25 years. The most important contributions are: a) national and regional meetings for lean tools dissemination; b) training for the development of Continuous Improvement practices in organizations; c) exchange commissions (university, quality, SMEs, etc.), to deepen the concepts of continuous improvement; d) various meeting points for the exchange of information and concrete experiences, related to continuous improvement, excellence in management, and the dissemination of tools such as Hoshin Kanri (Formento, 2011). More recently, SAMECO has launched two graduated courses in conjunction with the National University of General Sarmiento, both virtual right now (see https://sameco.org.ar/capacitacion/).

A third group is related to public institutions and academic organizations, researching, assessing, and teaching these management tools in the last fifteen years. It is worth mentioning some works in the master's degree in quality management at the National Technological University (UTN), Regional Faculties of Buenos Aires and Avellaneda. Also, some industrial engineering careers have incorporated contents on this management system (National Engineering Faculties of Lomas de Zamora, Salta, and La Plata). The CEMA University, privately managed in Buenos Aires, also stands out. However, university diffusion is not adequate nor enough ${ }^{16}$. The National University of General Sarmiento y very proactive also in this field, and the University of Buenos Aires is developing some graduate courses in the last five years.

Another crucial agent in the diffusion of lean tools is the National Institute of Industrial Technology (INTI). It created in 2004 the INTI Center for Management Technologies, working in assessing and training Argentine firms and organizations with these tools. More recently, in October 2017, it was launched the Kaizen Tango project, which is the result of an agreement between the Japanese International Cooperation Agency (JICA), the National Labor Ministry, and INTI, which is in charge of the implementation. In this framework, for five years, more than 100 Argentine SMEs are foreseen to be trained with kaizen tools to improve their productivity and competitiveness. Till now, in-plant technical assistance reached 71 SMEs in the textile, agri-food, metalworking, automotive, leather and footwear,

Health Services 2.00\%; Education (universities) 1.50\%; Government Services $3.75 \%$; Chambers and Other Organizations $2.00 \%$; Telecommunication Services $2.50 \%$; Transportation Services $0.50 \%$.

${ }^{16}$ Four universities receive training and support from AOTS for lean tools: National University of the Center of Buenos Aires Province, National University of Córdoba (Faculty of Economics), University of Buenos Aires, and the University of Morón. The first three are public institutions and the latter is private. 
home appliances, and medical equipment productive sectors. It involved 50 consultants in management technologies from INTI, five Japanese experts in Kaizen, and one specialized in value chain development. The experience involved more than 2,000 trained people, many of them in participating firms ${ }^{17}$.

\subsection{IMPLEMENTATION CONDITIONS FOR HOSHIN KANRI:}

Dissemination in the business sphere has also been timely, where the Hoshin Kanri has had very few cases of implementation among national companies in general, and SMEs in particular. In the latter case, there are very few studies of this type of company that allow them to be counted as adopters of these management tools. The survey of SMEs in Argentina only shows very few cases (cf. Yacuzzi et al., 2011; Formento, 2011), 5 in total. Also at the international level, there is little evidence of the adoption of Hoshin Kanri by SMEs (cfr. Jolayemi, 2008: 318; Löfving et al., 2015; Jalali-Roudsari and Murray, 2013).

Regarding the analysis of the possibilities of implementing the Hoshin Kanri in SMEs, the characteristics of this type of companies present some patterns of business behavior that can favor or inhibit this implementation process:

- Management usually has a predominant focus on the operational and little focus on the long term. This is an obstacle to the strategic logic of the Hoshin Plan.

- SMEs have structural shortages of resources and capacities, which condition their strategic behavior. The Hoshin Plan must be extremely creative in this regard.

- The strategic vision of the management or direction is seldom formalized in writing. The Hoshin is a written plan, which is a barrier for smaller SMEs.

- Improvement and change projects are also usually informal, reactive or adaptive to context change, not written, without formal allocation of resources and human capital (personnel involved are not specifically assigned to strategic tasks) (cfr. Arciénaga, 2005: 21; Arciénaga et al., 2018: 24).

- SMEs have flattened structures with few hierarchical levels, very flexible to adapt to changing environments. This can facilitate the discussion of the Hoshin plan through the application of catchball and nemawashi. Hoshin Kanri seems to work well in SMEs where ownership and decision making are one (Kesterson, 2015: 79).

- The management style is to a large extent dominated by crises and emerging daily problems, and not by medium or long-term situations or scenarios. This style is an important obstacle to overcome since it is usually already a routine and internal firm's logic.

\footnotetext{
${ }^{17}$ See more references in the INTI official webpage: https://www.inti.gob.ar/noticias/16-cooperacion-internacional/1337kaizen-tango-mas-empresas-se-suman-al-programa-de-mejora-de-la-productividad
} 
- The management has great personalism (business owner or manager). Few people integrate driving (a single person or part of their family group). This can be positive due to the smaller number of managers to be convinced to implement the Hoshin Plan.

An interesting case study is that of Swedish SMEs, in which the Hoshin adoption process was favored with a previous study of the same, identifying three basic strategies (Löfving et al., 2015: 6): a) need for an extensive action of familiarization of companies with the Hoshin Kanri; b) flexibility in starting companies with different tools (interviews, case analysis, visits to companies with plans, etc.); c) counteract the operational logic of management with an initiation to the Hoshin Plan through a "learning by use". The companies analyzed did not have a management system based on total quality or lean production to make use of the Hoshin Kanri. For other Swedish SMEs, Barth (2003: 135) also highlighted two important administrative mechanisms for coping with critical aspects of strategic implementation: a) managerial skills and knowledge needed to implement and to follow the competitive strategy chosen by the firm; b) design of a flexible organization structure to afford continuous changing as the small firm evolves.

\section{CONCLUSION:}

A first conclusion that emerges from the bibliographic survey is the ability of Hoshin Kanri to solve organizational problems critically connected to the implementation of a strategic plan: organizational alignment, consensus between hierarchical levels of the company, identification of actions to solve how to implement a plan, connection of objectives and goals with daily actions at all levels, and inclusive capacity of all staff and workers. Cascading and participative processes also develop strategic and intellectual capabilities within the organization.

A second issue is related to the spread of Hoshin Kanri in Argentina. To a large extent, the experience is confined to subsidiaries of multinationals and their subcontracting chain. National companies have little experience, and SMEs even less. Furthermore, the role of universities is still limited, and focused on teaching only classical tools, but without almost no involvement in implementing experiences. Hoshin Kanri dissemination is growing slowly with the protagonism of public and private actors.

Regarding the application in Argentine SMEs, they have some qualities or characteristics that facilitate the process of adopting this management system, and others that tend to inhibit its effective implementation. The basic initiation strategies are those of familiarization, flexibility in initiation tools, and learning by using. 


\section{REFERENCES}

Akao, Y. (1991, ed.). Hoshin Kanri: Policy Deployment for Successful TQM. Cambridge, MA: Productivity Press. Publish in Japanese as Hoshin Kanri katsuyo no jissai, in 1988.

Arciénaga, A. (2005). Modelo Argentino de Innovación (Argentine Model of Innovation). La Plata: Comisión de Investigaciones Científicas.

Arciénaga, A., Villanueva, B., and Solá, H. (2017). Hoshin Kanri y Posibilidades de Aplicación en PYMEs Argentinas (Hoshin Kanri and its Possible Application to Argentine SMEs). Presentation in X Simposio Internacional de Ingeniería Industrial: Actualidad y Nuevas Tendencias 2017, Oberá, Argentina, September 27 to 29.

Arciénaga, A.A., Nielsen, J., Bacarini, H., Martinelli, S., Kofuji, S.T., and García Díaz, J.F. (2018). Technology and Innovation Management in Higher Education - Cases from Latin America and European Union. Administrative Science, Vol. 8, № 2, pp.1-34

Ayala, N. F. (2010). A Utilização do Hoshin Kanri para Desdobramento da Estratégia no Contexto da Produção Enxuta (Utilization of Hoshin Kanri for Strategy Deployment in the Framework of Lean Production). Porto Alegre: Universidade Federal do Rio Grande do Sul. Master thesis.

Barth, H. (2003). Strategic Fit among Competitive Strategy, Administrative Mechanisms, and Performance: a Comparative Study of Small Firms in Mature and New Industries. Journal of Small Business Management, Vol. 41, No 2, pp. 133-147.

Boisvert, L. (2012). Strategic Planning Using Hoshin Kanri. Salem NH: GOAL/QPC.

Bourgine, P., Collet, P., and Parrend, P. (2017, eds.). First Complex Systems Digital Campus World EConference 2015, Springer Proceedings in Complexity. Cham, Switzerland: Springer International Publishing.

Bryson, J.M. (2011). Strategic Planning for Public and Nonprofit Organizations. A Guide to Strengthening and Sustaining Organizational Achievement. Hoboken, NJ: John Wiley \& Sons.

Campos, V.F. (1996). Gerenciamento pelas Diretrizes (Management by the Guidelines). Belo Horizonte: Fundação Christiano Ottoni, Escola de Engenharia da Universidade Federal da Mina Gerais.

Cudney, E. (2009). Using Hoshin Kanri to Improve Value Stream. New York: CRC Press.

Dennis, P. (2006). Getting the Right Things Done: A Leader's Guide to Planning and Execution. Cambridge, MA: Lean Enterprise Institute.

Drucker, P. (1992). The New Society of Organizations. Harvard Business Review. Sep.-October, pp. $95-$ 104.

Formento, H. (2011). http://caballerosdelamejoracontinua.blogspot.com.ar/2011/10/claves-para-unamejora-continua.html.

Ghobadian, A. and Gallear, D. (1997). TQM and Organization size. International Journal of Operations \& Production Management. Vol. 17, No. 2, pp. 121-163. 
Ghonim, M. A., Khashaba, N. M., Al-Najaar, H. M., \& Khashan, M. A. (2020). Strategic Alignment and its Impact on Decision Effectiveness: a Comprehensive Model. International Journal of Emerging Markets, Vol. ahead-of-print, $\mathrm{N}^{\mathrm{o}}$ ahead-of-print.

Hrebiniak, L. G. (2006). Obstacles to Effective Strategy Implementation. Organizational Dynamics, Vol. $35, \mathrm{~N}^{\mathrm{o}} 1$, pp. 12-31.

Hudson, M.; Smart, A. and Bourne, M. (2001). Theory and Practice in SME Performance Measurement Systems. International Journal of Operation and Production Management. Vol. 21, pp. 1096-1115.

Hutchins, D. (2008). Hoshin Kanri: The Strategic Approach to Continuous Improvement. Aldershot: Gower Publishing.

Jackson, T.L. (2006). Hoshin Kanri for the Lean Enterprise: Developing Competitive Capabilities and Managing Profit. Productivity Press.

Jalali-Roudsari M. and Murray S. (2013). Enabling initiation of a lean management system in SMEs: a case study of a high performance plastics manufacturer. Proceedings of the 11th International Conference on Manufacturing Research (ICMR2013), Cranfield University, UK, 19th - 20th September 2013, pp 419-424. Available at: https://dspace.lib.cranfield.ac.uk/handle/1826/9499 Access: 15/05/2021.

Jolayemi, Joel K. (2008). Hoshin Kanri and Hoshin Process: A Review and Literature Survey. Total Quality Management. Vol. 19, No. 3, March, pp. 295-320.

Kathuria, R., Joshi, M. P., and Porth, S. J. (2007). Organizational Alignment and Performance: Past, Present and Future. Management Decision, Vol. 45, No 3, pp. 503-517.

Kesterson, R. K. (2015). The Basics of Hoshin Kanri. Boca Ratón, Fl: CRC Press.

Kondo, Yoshio (1998). Hoshin Kanri -a Participative Way for Quality Management in Japan. The TQM Magazine. Vol. 10, Number 6, pp. 425-431.

Löfving, M., Melander, A., and Elgh, F. (2015). Initiation of Hoshin Kanri in SMEs using a tentative process. Paper presented in 22nd EurOMA Conference. Available at: http://urn.kb.se/resolve?urn=urn:nbn:se:hj:diva-28692. Access on: 14/05/2015.

Lorange, P. (1998). Strategy implementation: the New Realities. Long Range Planning, Vol. 31, N 1, pp. $18-29$.

Marksberry, L. (2011). The Theory behind Hoshin: a Quantitative Investigation of Toyota's Strategic Planning Process. International Journal of Business Innovation and Research. Vol. 5, Number 3, pp. 347 370.

Masai, P., Parrend, P., Toussaint, N., and Collet, P. (2017). Is the Lean Organization a Complex System? Included in Bourgine et al. (eds.), pp. 55-69.

Miniace, J.N. and Falter, E. (1996). Communication: A key factor in strategy implementation. Planning Review, Vol. 24, N 1, pp. 26-30. 
O'Gorman, D. (2012). What Japanese Companies must do to Create a Second Economic Miracle. Ivey Business Journal. November-December. Available at: http://iveybusinessjournal.com/topics/innovation/what-japanese-companies-must-do-to-create-a-secondeconomic-miracle\#.VDHjOmeHhac Access on: 5/10/2014.

Olve, N.; Petri, C.; Roy, J. and Roy, S. (2003): Making Scorecards Actionable. Balancing Strategy and Control. Sussex (England): John Wiley \& Sons.

Raps, A. (2005). Strategy implementation - an insurmountable obstacle? Handbook of Business Strategy, Vol. 6, $\mathrm{N}^{\mathrm{o}}$ 1, pp. 141-146.

Sobek II, D.K. and Smalley, A. (2008). Understanding A3 Thinking - Critical Component of Toyota's PDCA Management System. New York: Productivity Press.

Tennants, C. and Roberts, P. (2001). Hoshin Kanri - Implementing the Catchball Process. Long Range Planning Journal, vol. 34, pp. 287-308.

Tosti, D.T. and Jackson, S.F. (2001). Organizational Alignment. IChangeWorld Consulting LLC. Available at: http://www.ichangeworld.com/docs/icwoa0303.pdf Access on 10/10/2018.

Witcher, B. and Butterworth, R. (2000). Hoshin Kanri at Hewlett Packard. Journal of General Management. Vol. 25, $\mathrm{N}^{\mathrm{o}}$ 4, summer, pp. 70-85.

Witcher, B.J., Chau, V.S., and Harding, P. (2008). Dynamic Capabilities: Top Executive Audits and Hoshin Kanri at Nissan South Africa. International Journal of Operations \& Production Management, Vol. 28, No 6, pp. 540-561.

Witcher, B.J. (2014). Hoshin Kanri through the Eyes of English Language Texts. Journal of Business Studies, vol. 53, nro 3, pp. $72-90$.

Wood, G.R. and Munshi, K.F. (1991). Hoshin Kanri: A Systematic Approach to Breakthrough Improvement. Total Quality Management, Vol. 2, No 3, pp. 213-226.

Yacuzzi, E. (2005). La Gestión Hoshin: Modelos, Aplicaciones, Características Distintivas. Universidad CEMA, Buenos Aires, mimeo.

Yacuzzi, E., Arancio, E., Alfonso, D., Esteche, M.E., and Niro, V. (2011): Cómo Realizar un Plan Hoshin: Aplicación en Ascensores Telesí S.R.L. (How to Carry out a Hoshin Plan: Implementation in Ascensores Telesí SRL). UCEMA, Documento No 463, August. 